\title{
Impact of harvesting and fire on Phragmites australis reed quality in Tembe Elephant Park, Maputaland
}

\author{
M.W. van Rooyen, C.A. Tosh, N. van Rooyen, W.S. MatTheWS and M.J.S. Kellerman
}

Van Rooyen, M.W., C.A. Tosh, N. van Rooyen, W.S. Matthews and M.J.S. Kellerman. 2004. Impact of harvesting and fire on Phragmites australis reed quality in Tembe Elephant Park, Maputaland. Koedoe 47(1): 31-40. Pretoria. ISSN 0075-6458.

In Maputaland, South Africa, the common reed (Phragmites australis) is used extensively for hut building, fencing, craftwork and thatching. As a result of over-harvesting most reed beds in communal areas have been degraded and are no longer producing reeds of the desired quality. At present the most productive reed beds are all found in conservation areas. The KwaMsomi area of the Muzi Swamp in the Tembe Elephant Park has been allocated to the Sibonisweni community for harvesting purposes. This community has recently requested Ezemvelo KwaZulu-Natal Wildlife for additional areas for harvesting on the grounds that the current site was no longer yielding reeds of suitable quality. The main objective of this study was therefore to determine whether there was a decline in reed quality in the KwaMsomi harvested area. The results of this study suggest that harvested areas contained more thin, short reeds than unharvested areas. Fire can be used to increase reed diameter in harvested areas, but will not significantly affect reed height. Ideally, reeds should only be harvested after the active growth period, when most of the nutrient reserves have been translocated to the rhizomes and the buds are still dormant. To improve reed quality a three-year rotational harvesting programme should be implemented to allow the reeds to recover fully before being harvested again.

Keywords: common reed, fire, harvesting, KwaZulu-Natal, Muzi Swamp, Phragmites australis, sustainable utilisation.

M.W. van Rooyen, C.A. Tosh, N. van Rooyen and M.J.S. Kellerman, Department of Botany, University of Pretoria, Pretoria, 0002 Republic of South Africa; W.S. Matthews, Ezemvelo KwaZulu-Natal Wildife, P O Box 356, KwaNgwanase, 3973 Republic of South Africa.

\section{Introduction}

Thousands of rural South Africans in KwaZulu-Natal depend on biological resources for their day-to-day survival. Access to this natural capital provides a crucial contribution to their livelihood and is a buffer against poverty and an opportunity for self-employment (Wynberg 2002).

The common reed, Phragmites australis (Cav.) Trin. ex Steud., is a widespread, morphologically highly-variable key wetland species that provides many essential ecosystem services. It is a major component of freshwater bodies in temperate regions throughout the world and often forms large monospecific stands at the interface between land and water (Ingram et al. 1980; Clevering 1999; Clevering \& Lissner 1999; Karunaratne \& Asaeda 2000; Asaeda \& Karunaratne 2000).

Large-scale decline of Phragmites australis stands in European freshwater bodies has stimulated intensive research on this species and a large body of literature has been accumulated over the past decades. The effects of environmental factors such as chemical composition of the soil and water, altitude, temperature stress and mineral uptake (Weisner 1996; Klimes et al. 1999; Cízková \& Lukavska 1999; Cízková et al. 2001b; Batty et al. 2002) and management practices such as mowing, cutting and burning on biomass 
production of Phragmites australis have been well documented for European conditions (Haslam 1970; Van der Toorn \& Mook 1982; Mook \& Van der Toorn 1982; Ostendorp 1995, 1999). Autecological studies on Phragmites australis have not been conducted in South African conditions. Several studies have reported on changes in the distribution and extent of Phragmites australis stands in South Africa (e.g., Weisser 1981; Kotschy et al. 2000). Two studies have investigated the impact of reed harvesting in the Fuyeni reed bed in KwaZulu-Natal (Frankland 1982; McKean 2001).

In southern Africa, the common reed is used extensively for non-food commodities. The thick hollow stems are widely used for building walls, fences and bomas (Van Wyk \& Gericke 2000). Stems are woven into traditional sitting mats and winnowing baskets and also used for arrow shafts, tobacco pipestems, flutes and parts of musical instruments. The common reed is also used for traditional medicine (Van Wyk \& Gericke 2000).

In Maputaland, northern KwaZulu-Natal, reeds are in demand for hut building, fencing, craftwork and thatching (Begg 1988). However, due to over-harvesting, most reed beds in communal areas have been degraded and are no longer producing reeds of the desired quality. At present, the most productive reed beds are all situated in conservation areas. To prevent the degradation of reed beds in conservation areas there is an urgent need to establish levels of sustainable utilisation for this resource.

When the Tembe Elephant Park was proclaimed, part of the agreement with the neighbouring communities was that they would be allowed to harvest particular renewable natural resources inside the park at sustainable levels. One particular area of the Muzi Swamp was specifically allocated to the Sibonisweni community to harvest Phragmites australis for non-commercial use. The harvesters of this community, enter the park at KwaMsomi gate and may harvest reeds for approximately $1.5 \mathrm{~km}$ northwards along the swamp. When the park was fenced in 1983 the fenceline bisected a monoculture of Phragmites australis across the Muzi Swamp at KwaMsomi. The reed beds on the outside of the park have since been almost destroyed leading to increased pressure for additional collection inside the park. Other areas of the Muzi Swamp have been set aside for harvesting by other communities and access to those areas is obtained via other gates.

The Sibonisweni community have recently requested Ezemvelo KwaZulu-Natal Wildlife for additional areas for harvesting on the grounds that the current site was no longer yielding reeds of suitable quality. However, conservation authorities are concerned that this may lead to non-sustainable levels of harvest because the reeds are being sold commercially and not merely for local use as stipulated by the original agreement.

The primary aim of this study was to determine whether there was a decline in reed quality in the KwaMsomi harvested areas. However, because accidental fires had swept through sections of both the harvested and non-harvested areas of the Muzi Swamp in the previous winter, an opportunity existed to investigate the use of fire to improve reed quality. The second aim of the study was therefore to determine the effect of fire on reed quality. Based on these results suggestions for sustainable harvesting are made.

\section{Study area}

The Tembe Elephant Park is located in northern KwaZulu-Natal with its northern boundary bordering Mozambique. The park covers approximately 30000 ha and was proclaimed in 1983 as a haven for the Maputaland elephant population in an effort to reduce the human-elephant conflict. The park is situated in the core area of the Maputaland Centre of Endemism (Van Wyk $\&$ Smith 2001) and the conservation of many rare and endemic plant and animal species is one of the park's main objectives. 
The Muzi Swamp covers about 560 ha in the eastern part of the Tembe Elephant Park. This is the most important wetland system in the park and is the only permanent water supply in the area. It stretches for $25 \mathrm{~km}$ from south to north, running in a slightly easterly direction. For most of its length it is covered by the Phragmites australis community (Matthews et al. 2001).

The climate of the area can be described as subtropical, with hot summers and cool to warm winters (Schulze 1982). Rainfall is mainly in summer, but winter showers are known to occur. Mean annual rainfall at Sihangwane (in Tembe Elephant Park) is $722 \mathrm{~mm}$, but ranges from $245 \mathrm{~mm}$ to a maximum of $2105 \mathrm{~mm}$ per annum (Matthews et al. 2001). The period preceding the harvest was exceptionally wet and $1541 \mathrm{~mm}$ of rain fell from August 1999 to June 2000.

\section{Material and methods}

The effects of two factors, viz. utilisation and burning on reed quality were investigated. Reed quality was determined in terms of reed diameter, reed height and reed density. Four sites, differing in utilisation/burning status were selected. These sites were: (a) unutilised, unburnt; (b) unutilised, burnt; (c) utilised, unburnt and (d) utilised, burnt. Burnt and unburnt sites within a utilisation zone were adjacent to each other to minimise possible effects of other environmental factors. The utilised sites were approximately $500 \mathrm{~m}$ from KwaMsomi gate and represented an area under relatively high utilisation pressure. The unutilised sites were approximately $1.8 \mathrm{~km}$ from KwaMsomi Gate in an area of the swamp that may not be harvested by the neighbouring communities.

At each site eight randomly selected samples of $1 \mathrm{~m}^{2}$ were harvested in July. All reeds within the $1 \mathrm{~m}^{2}$ sample area were cut at water level and the height and diameter of each reed measured. Total reed height was obtained by correcting for water depth. Frequency distributions of height and diameter classes were calculated for each site.

Data were analysed with Statistica 6 (StatSoft Inc, Tulsa Oklahoma) by performing a factorial ANOVA and Scheffe's post hoc test to determine statistically significant differences between treatments. The sig-

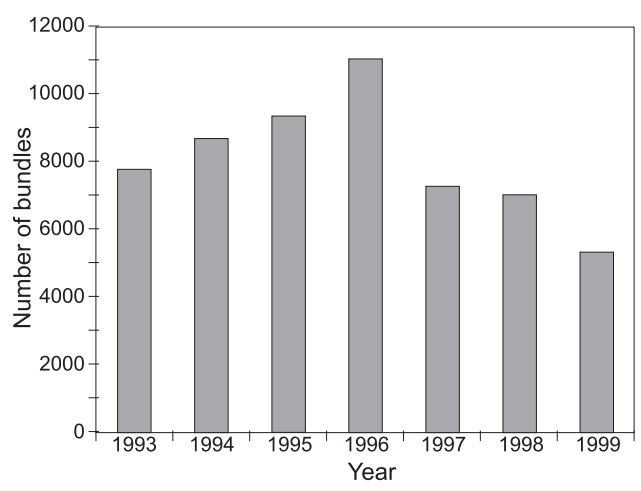

Fig. 1. Annual reed harvest from the Muzi Swamp from 1993 to 1999 (Kyle 2000).

nificant differences $(p<0.05)$ are indicated in the figures by different superscripts above the bars.

\section{Results}

\section{Harvesting pattern}

Annual reed harvest from the Muzi Swamp increased from 1993 to a maximum off-take in 1996, whereafter reed harvesting decreased (Fig. 1) (Kyle 2000). Until 1996 no harvesting quotas were imposed by conservation authorities in the Tembe Elephant Park. The authorities exercised control over the harvesting only by delimiting the area that may be harvested and controlling the number of reed cutters entering the park at KwaMsomi gate per day. The number of bundles harvested during that period was therefore, determined largely by the demand for reeds. Monthly reed off-take from the Muzi Swamp in 1999 illustrates that approximately $65 \%$ of all bundles were harvested from March to August (Fig. 2).

Harvesters in the Tembe Elephant Park do not select reeds of only a particular thickness and height to harvest. Usually an area is selected and all reeds within that area are harvested (Fig. 3). The cut reeds are sorted into bundles containing reeds of even thick- 


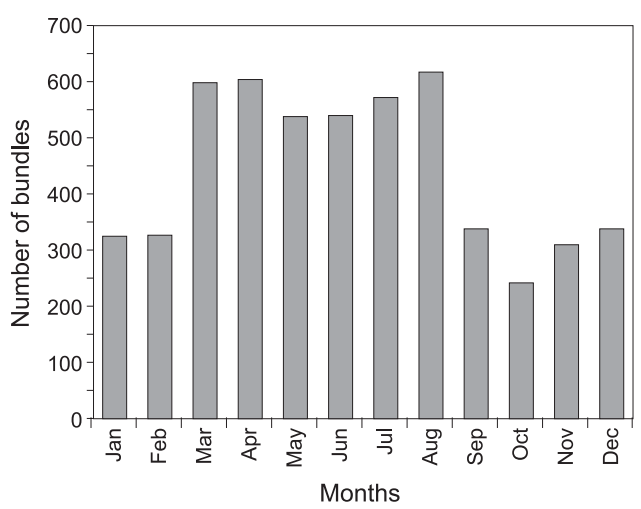

Fig. 2. Monthly reed harvest from the Muzi Swamp in 1999 (Kyle 2000).

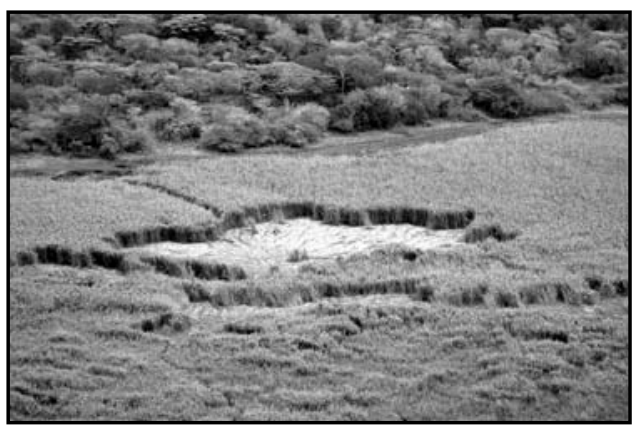

Fig. 3. Aerial view of a harvested area in the Muzi Swamp.

ness and length. The taller and thicker reeds are the most prized and of the highest quality. For this study reeds of $>8 \mathrm{~mm}$ in diameter and $>2.1 \mathrm{~m}$ in height indicate the availability of the most desirable reeds. In his study of Phragmites australis harvesting in the Fuyeni reed beds McKean (2001) regarded usable reeds in the Fuyeni reed bed as $>10 \mathrm{~mm}$ in diameter and $>2.5 \mathrm{~m}$ tall. Because of the apparent difference in harvesting pattern in the Fuyeni reed bed and the Muzi Swamp the definition used in this study is different to that used by McKean (2001). $\mathbf{a}$

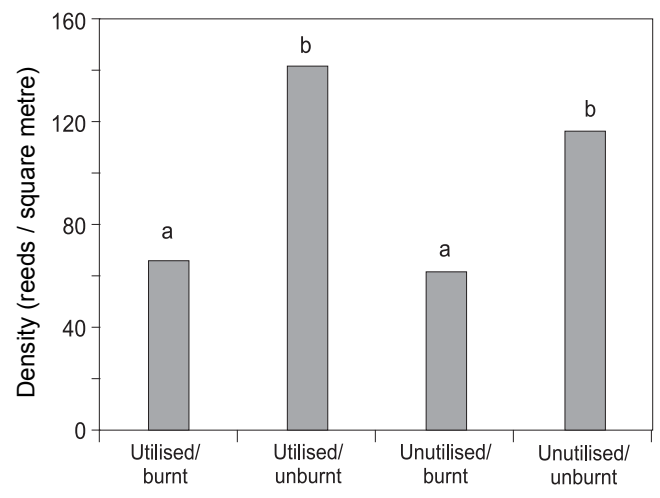

b

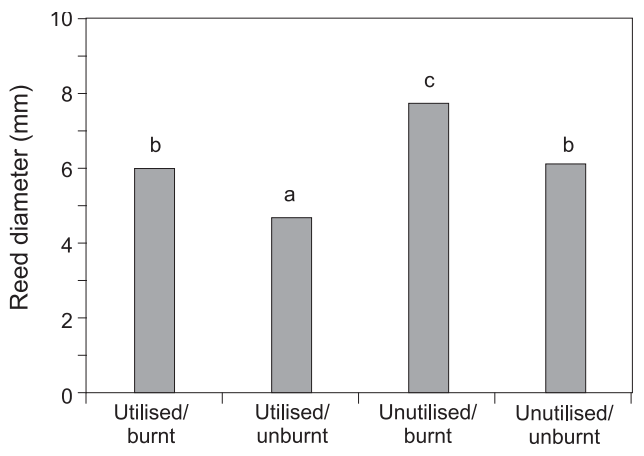

c

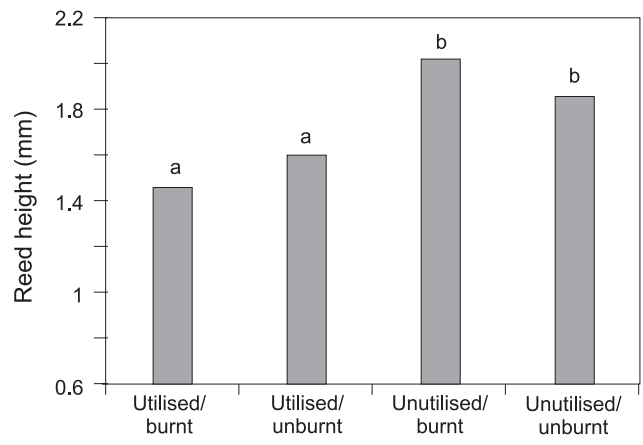

Fig. 4. Phragmites australis reed quality under different utilisation and burning regimes in the Muzi Swamp, Tembe Elephant Park as determined by harvesting trials in 2000: (a) Mean reed density per $\mathrm{m}^{2}$; (b) mean reed diameter; and (c) mean reed height. Bars with different superscripts are significantly different $(p<0.05)$. 
Table 1

Results of factorial analyses of variance (ANOVAs) examining the effects of fire and harvesting on reed density, reed diameter and reed height in the Muzi Swamp, Tembe Elephant Park

\begin{tabular}{lccc}
\hline Factor & & $p$-values \\
& Reed density & Reed diameter & Reed height \\
\hline Fire & $<0.001$ & $<0.001$ & 0.073 \\
Utilisation & 0.234 & $<0.001$ & $<0.001$ \\
Fire $x$ utilisation interaction & 0.410 & 0.673 & 0.297 \\
\hline
\end{tabular}

\section{Utilisation}

Density was not significantly affected by utilisation ( $p=0.234$, Table 1$)$ within a burning treatment (Fig. 4a). Although reed density was higher when the reeds were utilised than when unutilised in the absence of fire, this difference was not statistically significant.

Unutilised sites produced significantly thicker $(p<0.001$, Table 1$)$ reeds both in the presence and absence of fire (Fig. 4b). The frequency distribution of reed diameter classes (Fig. 5) gives a more detailed indication of the effects of utilisation and fire. At the unburnt sites, almost no reeds thicker than $8 \mathrm{~mm}$ were produced in the utilised area ( $2.7 \%$ of all reeds, Fig. 5 c), whereas $13.0 \%$ of the reeds produced in the unutilised area (Fig. 5d) were $>8 \mathrm{~mm}$ in diameter. At the burnt sites, utilisation reduced the percentage of reeds $>8 \mathrm{~mm}$ thick from $23.9 \%$ at the unutilised site (Fig. 5b) to $15.0 \%$ in the utilised site (Fig. 5a). In utilised areas no reeds with a diameter $>14 \mathrm{~mm}$ were recorded, whereas reeds up to $18 \mathrm{~mm}$ in diameter were recorded in unutilised areas.

Reeds were not only thicker but also significantly taller $(p<0.001$, Table 1$)$ at unutilised sites than at utilised sites (Fig. 4c). In the absence of fire, utilisation reduced the percentage of reeds taller than $2.1 \mathrm{~m}$ from $33.0 \%$ (Fig. 6d) to only $7.5 \%$ in the utilised area (Fig. 6c). After fire, only $11.7 \%$ of the reeds were $>2.1 \mathrm{~m}$ tall at the utilised sites (Fig. 6a) as against $39.7 \%$ at the unutilised sites (Fig. 6b).
Fire

Fire significantly reduced mean reed density $(p<0.001$, Table 1) at both the harvested and non-harvested sites (Fig. 4a), but significantly increased mean reed diameter $(\mathrm{p}<0.001$, Table 1) at both harvested and non-harvested sites (Fig. 4b). In the unutilised zone stem diameter classes $>8 \mathrm{~mm}$ constituted $23.9 \%$ of all reeds after fire (Fig. 5b) as against $13.0 \%$ without fire (Fig. 5d). However, because of the two-fold difference in reed density, the density of preferred reeds is approximately 15 reeds $/ \mathrm{m}^{2}$ in both cases. In the utilised area, fire had a greater effect and only $2.7 \%$ of the reeds in the unburnt area (Fig. 5 c) were $>8 \mathrm{~mm}$ thick, whereas $15.0 \%$ were $>8 \mathrm{~mm}$ thick after fire (Fig. 5a). Even taking the difference in density into account, the number of thick reeds is still more after fire, with the burnt area yielding approximately 10 reeds $/ \mathrm{m}^{2}$ in these size classes as opposed to only 4 reeds $/ \mathrm{m}^{2}$ in the unburnt area.

Fire did not significantly affect mean reed height $(p=0.073$, Table 1) in either the utilised or unutilised zone (Fig. 4c). The percentage contribution of reeds $>2.1 \mathrm{~m}$ tall were more or less equal in the unutilised zone whether the area had been burnt or not, with $39.7 \%$ of all reeds in the unutilised burnt zone (Fig. 6b) as against $33.0 \%$ in the unutilised, unburnt zone (Fig. 6d). However, if the difference in density is accounted for, the unburnt treatment will yield more tall reeds to harvest (38 reeds $/ \mathrm{m}^{2}$ as against 25 reeds $/ \mathrm{m}^{2}$ ). In the utilised area only $7.5 \%$ 
Burnt
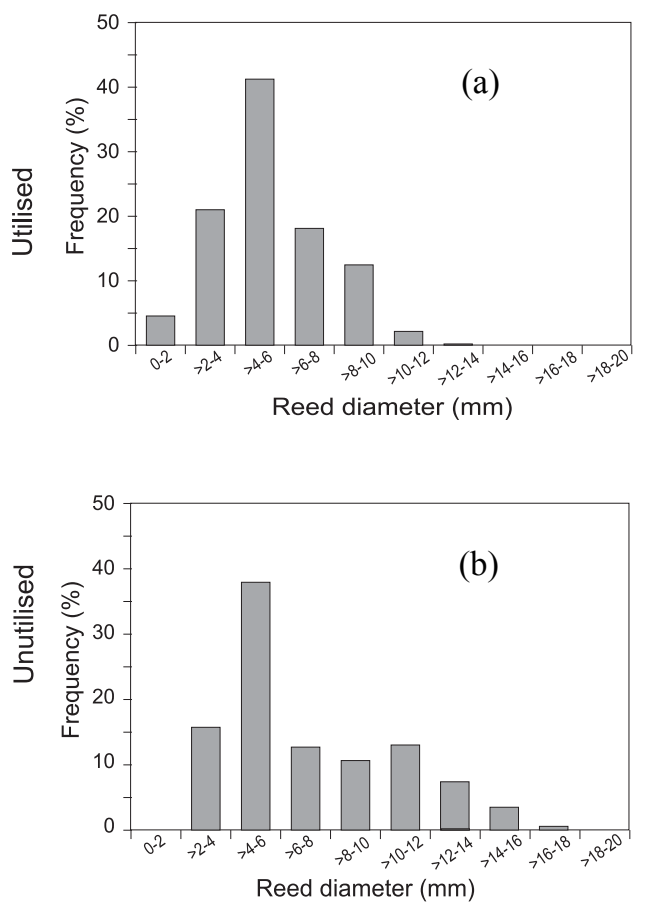

Unburnt
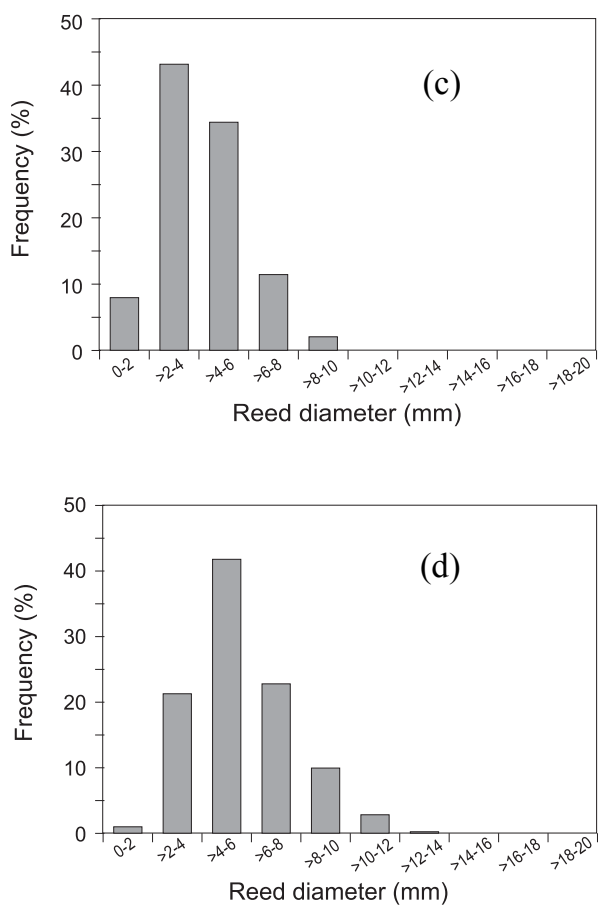

Fig. 5. Frequency distribution of different diameter size classes under different utilisation regimes in the Muzi Swamp, Tembe Elephant Park as determined by harvesting trials in 2000. (a) burnt, utilised area; (b) burnt, unutilised area; (c) unburnt, utilised area; and (d) unburnt, unutilised area.

of the unburnt reeds were $>2.1 \mathrm{~m}$ tall (Fig. 6c) as opposed to $11.7 \%$ of the reeds produced after fire (Fig. 6a). However, after accounting for the differences in density, there will be slightly more tall reeds to harvest in the unburnt area $\left(11\right.$ reeds $\left./ \mathrm{m}^{2}\right)$ than in the burnt area $\left(8\right.$ reeds $\left./ \mathrm{m}^{2}\right)$.

\section{Discussion}

In KwaZulu-Natal the degradation of wetlands has been extensive and future threats such as agricultural and rural development and global climate change remain high (Kotze \& O'Connor 2000). Over-harvesting of reeds has led to the degradation of reed beds and could eventually result in their total loss. To maintain the integrity of these systems and their inherent value to their users, it is crucial to establish levels of sustainable reed harvesting. In ecological terms, sustainable harvesting is defined as harvesting that has no long-term detrimental effect on the reproduction and regeneration of the population being harvested compared with similar non-harvested populations (Hall \& Bawa 1993).

Natural degeneration of Phragmites australis stands is known to occur and has often been associated with the accumulation of its own organic matter (Van der Putten et al. 1997; Clevering 1999; Lenssen et al. 2000). In waterlogged soil, microbial decomposition occurs under reduced conditions and 
Burnt
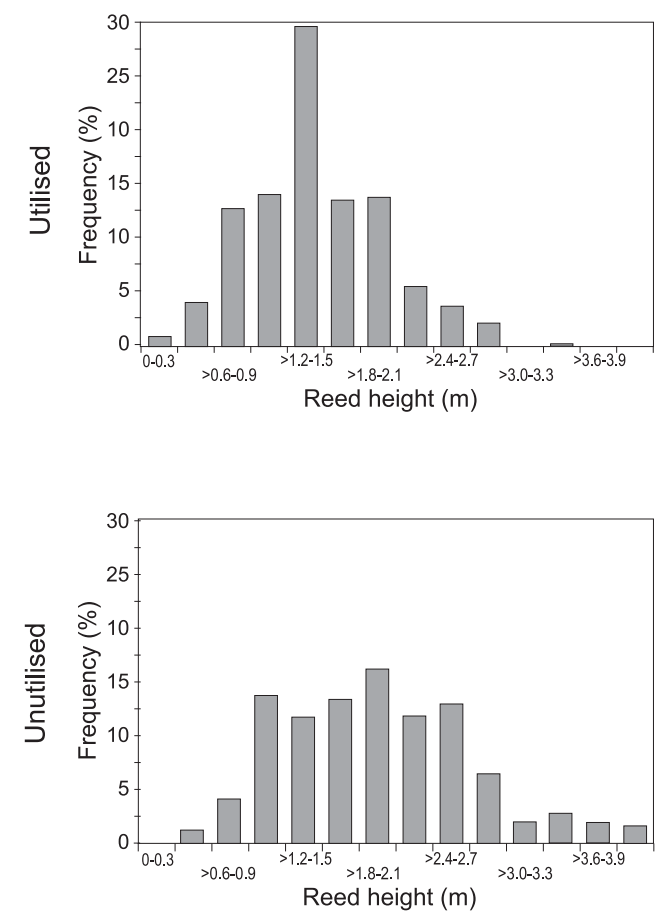

Unburnt
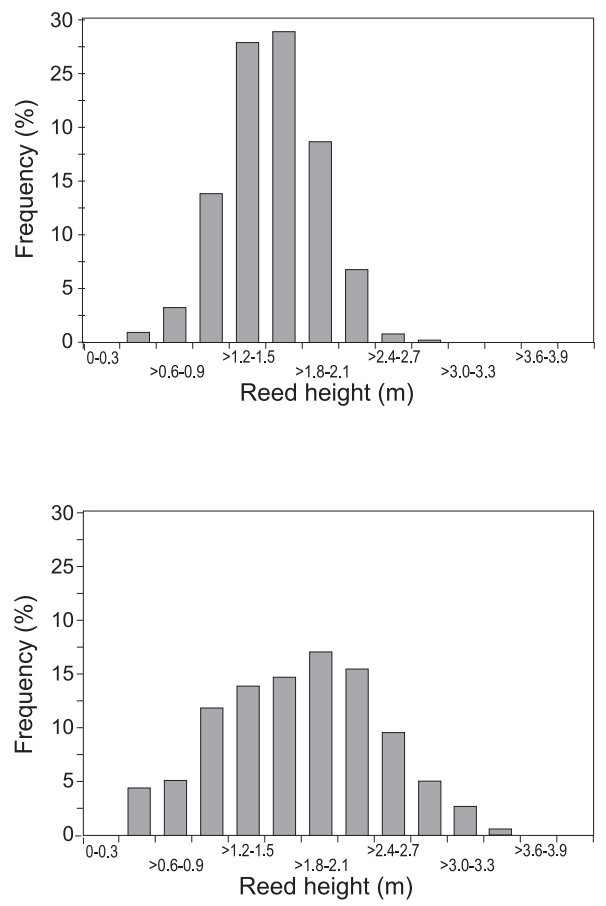

Fig. 6. Frequency distribution of different height classes under different utilisation regimes in the Muzi Swamp, Tembe Elephant Park as determined by harvesting trials in 2000. (a) burnt, utilised area; (b) burnt, unutilised area; (c) unburnt, utilised area; and (d) unburnt, unutilised area.

under these conditions of oxygen deficiency organic acids are formed that might be involved in the phytotoxic effect (Cízková et al. 1999). In this regard the input of discarded leaf litter to the reed beds by the harvesters might be contributing to the degradation of the swamp in the harvested areas.

The timing of reed harvesting is of critical importance. Phragmites australis is one of many wetland species that produces an extensive perennial rhizome system, which is able to tolerate long-term oxygen deficiency in flooded soils because of its internal aeration system (Cízková \& Bauer 1998; Soukup et al. 2000, 2002; Cízková et al. 2001a; Strand \& Weisner 2002). These rhizomes play a major role in the storage of car- bohydrate reserves that are the only source of carbohydrates during winter after shoots have died off. Buds are produced throughout the year but remain dormant near the soil surface for most of the time. The main burst of aerial annual shoot growth occurs in spring when developing shoots are supplied with stored carbohydrates from the rhizomes. Reeds mature during summer and shoot dry matter accumulation stops abruptly at the onset of flowering, which coincides with the start of senescence. At the end of the active growing stage, the accumulated dry matter is translocated to the rhizomes. Ideally, reeds should be harvested after the active growth period when most of the reserves have been translocated to the rhizomes, but the buds are still dormant or shoots are still 
under the soil surface (Mook \& Van der Toorn 1982). Most of the harvesting done in the Muzi Swamp (65\%) is done from May to August and therefore falls within this period. However, summer harvesting still accounts for $35 \%$ of the reed off-take, and especially when done year after year, this will deplete rhizome reserves, and is probably a major factor in the decline in reed quality in the KwaMsomi area.

Several previous studies have indicated that when shoots are damaged, either by harvesting, mowing or burning, the density of the replacement crop is increased (Frankland 1982; Van der Toorn \& Mook 1982; Ostendorp 1995, 1999). However, this contrasts with the findings of the present study where burning significantly decreased reed density and harvesting had no significant effect on density. In this study, we found that the response of reeds to harvesting corresponds closely with the findings of McKean (2001) who investigated the productivity and sustainable use of Phragmites australis in the Fuyeni reed bed in the Hluhluwe-Umfolozi Park, also in KwaZulu-Natal. In both these studies, harvested treatments showed higher reed densities than non-harvested treatments, but the differences were not statistically significant.

Previous studies have reported that after shoot damage by burning, cutting or mowing, replacement shoots are shorter and thinner (Van der Toorn \& Mook 1982; Ostendorp 1995, 1999; McKean 2001). The results of the present study confirmed that harvesting significantly reduced mean reed diameter and reed height, in both the burnt and unburnt areas. Consequently, thick and tall reeds are in short supply in the harvested areas. However, fire did not have the same effect. Fire significantly increased mean reed diameter while having no effect on mean reed height within a utilisation regime. In utilised areas, fire during the dormant season can, therefore, have a positive effect on reed diameter but not on reed height. In spite of the fact that reed density is reduced after fire, the density of thick reeds is higher after fire in the utilised zone. In unutilised areas, these differences are not as marked or can even be absent and because of the density difference more thick reeds are still found in unburnt areas.

In Europe, burning or mowing in winter is sometimes applied as countermeasure against the die-back of reeds (Ostendorp 1995, 1999). Although early season damage retards leaf and shoot growth, recovery is rapid and the maximum biomass production is not significantly lowered (Mook \& Van der Toorn 1982; McKean 2001). However, Ostendorp (1995, 1999) warns against the long-term negative effects of burning and mowing as management practices. Winter harvesting and burning lead to the dominance of weaker and thinner secondary shoots and in conditions where mechanical resistance to waves and washes is important, these management practices are not recommended (Ostendorp 1995, 1999).

\section{Management proposals}

Utilisation should be confined to the winter months (dormant season) when the damage to the reeds is minimal, because nutrient reserves have already been translocated to the rhizomes. Likewise, should fire be necessary, it should only be implemented during winter or early spring to minimise negative effects.

Continuous harvesting leads to the production of more short, thin reeds of limited value and could also deplete the carbohydrate reserves in the rhizomes. A system of rotational harvesting should be implemented even if this requires that an additional area of the Muzi Swamp should be set aside for harvesting. McKean (2001) investigated the effects of annual and biennial harvesting in the Fuyeni reed beds and concluded that it would be necessary to restrict harvesting of a given area to every second or preferably every third year to allow the reed bed to recover a full complement of large reeds. Harvesting on a tri-annual basis is therefore suggested for the Muzi Swamp. 
In unutilised areas, fire can be used to remove moribund material and to yield a larger proportion of tall and thick reeds. This study suggests that though fire will lead to more thick reeds in utilised areas these reeds will be shorter (although the latter is not statistically significant). The long-term effects of fire were not investigated in this study and it is therefore not recommended to burn on an annual basis.

\section{Conclusions}

The allegation of the Sibonisweni community that the quality of reeds in the harvested area has declined is confirmed. Compared with the unharvested area more short, thin reeds are being produced in the harvested area. Fire has the potential to increase reed diameter but does not significantly affect reed height.

To improve reed quality harvesting should be restricted to the dormant period when damage to the reeds is minimal. A three-year rotational harvesting programme is suggested as this should allow the reeds to recover fully, before being harvested again. Such a programme might, however, require an additional area to be set aside for harvesting.

\section{Acknowledgements}

The authors would like to acknowledge the assistance of Ezemvelo KwaZulu-Natal Wildlife. The material is based on research supported by the National Research Foundation (GUN 2053522).

\section{References}

Asaeda, T. \& S. Karunaratne. 2000. Dynamic modelling of the growth of Phragmites australis: model description. Aquatic Botany 67: 301-318.

BATTY, L.C., A.J.M. BAKer \& B.D. WheELER. 2002. Aluminium and phosphate uptake by Phragmites australis: the role of $\mathrm{Fe}, \mathrm{Mn}$ and $\mathrm{Al}$ root plaques. Annals of Botany 89: 443-449.

BegG, G.W. 1988. The wetlands of Natal. Natal Town and Regional Planning Commission, Pietermaritzburg.
Cízková, H. \& V. Bauer. 1998. Rhizome respiration of Phragmites australis: effect of rhizome age, temperature, and nutrient status of the habitat. Aquatic Botany 61: 239-253.

CízKová, H., H. Brix, J. Kopecky \& J. LuKavskÁ. 1999. Organic acids in the sediments of wetland dominated by Phragmites australis: evidence of phytotoxic concentrations. Aquatic Botany 64: 303-315.

CízkovÁ, H. \& J. Lukavská. 1999 Rhizome age structure of three populations of Phragmites australis (Cav.) Trin. ex Steud.: Biomass and mineral nutrient concentrations. Folia Geobotanica 34: 209-220.

Cízková, H., V. Istvánovics, V. Bauer \& L. BALÁzs. 2001a. Low levels of reserve carbohydrates in reed (Phragmites australis) stands of Kis-Balatow, Hungary. Aquatic Botany 69: 209216.

Cízková, H., L. Pechar, S. Husák, J. Kvet, V. Bauer, J. Radová \& K. Edwards. 2001b. Chemical characteristics of soils and pore waters on three wetland sites dominated by Phragmites australis: relation to vegetation composition and reed performance. Aquatic Botany 69: 235-249.

Clevering, O.A. 1999. Between- and within-population differences in Phragmites australis. 1. The effects of nutrients on seedling growth. Oecologia 121: 447-457.

Clevering, O.A. \& J. Lissner. 1999. Taxonomy, chromosome numbers, clonal diversity and population dynamics of Phragmites australis. Aquatic Botany 64: 185-208.

FranKLand, C. 1982. The impact of annual reed cutting on the ecology of the Fuyeni reedbed. Honours Dissertation, Department of Biological Sciences, University of Natal, Durban.

Hall, P. \& K. Bawa. 1993. Methods to assess the impact of extraction of non-timber tropical forest products on plant populations. Economic Botany 47: 234-247.

HasLAM, S.M. 1970 The development of the annual population in Phragmites communis Trin. Annals of Botany 34: 571-591.

IngRaM, H.A.P., A.M. BARClAY, A.M. COUgAR, J.G. Glover, B.M. Lynch \& J.I. SpRent. 1980. Phragmites performance in reedbeds of the Tay Estuary. Proceedings of the Royal society of Edinburgh 78B: 89-107.

KarunaratNE, S. \& T. Asaeda. 2000. Verification of a mathematical growth model of Phragmites australis using field data from two Scottish lochs. Folia Geobotanica 35: 419-432.

KLIMEŠ, L., J. KlimeŠovÁ \& H. CízkovÁ. 1999. Carbohydrate storage in rhizomes of Phragmites australis: the effects of altitude and rhizome age. Aquatic Botany 64: 105-110.

Kotschy, K.A., K.H. Rogers \& A.J. CARTER. 2000. Patterns of change in reed cover and distribution 
in a seasonal riverine wetland in South Africa. Folia Geobotanica 35: 363-373.

Kotze, D.C. \& T.G.O. O’CONNOR. 2000. Vegetation variation within and among palustrine wetlands along an altitudinal gradient in KwaZulu-Natal, South Africa. Plant Ecology 146: 77-96.

KYLE, R. 2000. A summary and some comments on resource utilization in the Tembe/Ndumo Game Reserve Complex during 1999. Internal Report KwaZulu-Natal Nature Conservation Services.

Lenssen, J.P.M., F.B.J. Menting, W.H. VAN Der PutTen \& C.W.P.M. Blom. 2000. Variation in species composition and species richness within Phragmites australis dominated riparian zones. Plant Ecology 147: 137-146.

Matthews, W.S., A.E. VAn WyK, N. Van Rooyen \& G.A. BothA. 2001. Vegetation of the Tembe Elephant Park, Maputaland, South Africa. South African Journal of Botany 67: 573-594.

MCKEAN, S.G. 2001. Productivity and sustainable use of Phragmites in the Fuyeni reedbed - Hluhluwe-Umfolozi Park - Management guideline for harvest. South African Journal of Botany 67: 274-280.

MOOK, J.H. \& J. vAN DER TOORN. 1982. The influence of environmental factors and management on stands of Phragmites australis. 2. Effects on yield and its relationships with shoot density. Journal of Applied Ecology 19: 501-517.

OSTENDORP, W. 1995. Effect of management on the mechanical stability of lakeside reeds in Lake Constance-Untersee. Acta Oecologica 16: 277 294.

OSTENDORP, W. 1999. Management impact on stand structure of lakeshore Phragmites reeds. International Review of Hydrobiology 84: 33-47.

SCHUlzE, R.E. 1982. Agrohydrology and agroclimatology of Natal. Agricultural catchments Research Unit, Report 14. University of Natal, Pietermaritzburg, South Africa.

Soukup, A., O. Votrubova \& H. Cízková. 2000. Internal segmentation of rhizomes of Phrag- mites australis: protection of the internal aeration system against being flooded. New Phytologist 145: 71-75.

Soukup, A., O. Votrubova \& H. CízKová. 2002. Development of anatomical structure of roots of Phragmites australis. New Phytologist 153: 277287.

Strand, V.V. \& S.E.B. WeISNER. 2002. Interactive effects of pressurized ventilation, water depth and substrate conditions on Phragmites australis. Oecologia 131: 490-497.

VAN DER Putten, W.H., B.A.M. Peters \& M.S. VAN DEN BERG. 1997. Effects of litter on substrate conditions and growth of emergent macrophytes. New Phytologist 135: 527-537.

VAN DER TOORN, J. \& J.H. MoOK. 1982. The influence of environmental factors and management on stands of Phragmites australis. 1. Effects of burning, frost and insect damage on shoot density and shoot size. Journal of Applied Ecology 19: 477-499.

VAN WyK, A.E. \& G.F. SMITH. 2001. Regions of floristic endemism in southern Africa: a review with emphasis on succulents. Pretoria: Umdaus Press.

VAn Wyk, B.E. \& N. Gericke. 2000. People's plants. Pretoria: Briza Publications.

WeIsner, S.E.B. 1996. Effects of organic sediment on performance of young Phragmites australis clones at different water depth treatments. Hydrobiologia 330: 189-194.

WeIsSER, P.J. \& R.J. PARSONS. 1981. Monitoring Phragmites australis increases from 1937 to 1976 in the Siyai Lagoon (Natal, South Africa) by means of air photo interpretation. Bothalia 13: 553-556.

WYNBERG, R. 2002. A decade of biodiversity conservation and use in South Africa: tracking progress from the Rio Earth Summit to the Johannesburg World Summit on Sustainable Development. South African Journal of Science 98: 233-243. 